\title{
Serum antioxidants as predictors of adult respiratory distress syndrome in patients with sepsis
}

\author{
Jonathan A. LeFF Polly E. Parsons Caroline E. Day \\ NAOYUKI TANIGUCHI MARIANNE JOCHUM HANS FRITZ \\ FredRick A. MOORE EUGENE E. MOORE JOE M. MCCORD \\ JOHN E. REPINE
}

Adult respiratory distress syndrome (ARDS) can develop as a complication of various disorders, including sepsis, but it has not been possible to identify which of the patients at risk will develop this serious disorder. We have investigated the ability of six markers, measured sequentially in blood, to predict development of ARDS in 26 patients with sepsis.

At the initial diagnosis of sepsis (6-24 $\mathrm{h}$ before the development of ARDS), serum manganese superoxide dismutase concentration and catalase activity were higher in the 6 patients who subsequently developed ARDS than in 20 patients who did not develop ARDS. These changes in antioxidant enzymes predicted the development of ARDS in septic patients with the same sensitivity, specificity, and efficiency as simultaneous assessments of serum lactate dehydrogenase activity and factor VIII concentration. By contrast, serum glutathione peroxidase activity and $\alpha_{1} \mathrm{Pi}$-elastase complex concentration did not differ at the initial diagnosis of sepsis between patients who did and did not subsequently develop ARDS, and were not as effective in predicting the development of ARDS.

Measurement of manganese superoxide dismutase and catalase, in addition to the other markers, should facilitate identification of patients at highest risk of ARDS and allow prospective treatment.

Lancet 1993; 341: 777-80.

\section{Introduction}

Adult respiratory distress syndrome (ARDS) is an acute inflammatory process characterised by neutrophil accumulation and oedema in the lungs and progressive hypoxaemia. ${ }^{1}$ ARDS occurs unpredictably as a complication in patients with sepsis and several other predisposing disorders. Since many common and diverse risk factors can lead to the development of ARDS, but do so only rarely, pretreatment of every patient at risk of ARDS is not practical. Understanding of ARDS is improving and various interventions that can limit inflammation have become available, so it has become important to identify accessible and repeatable markers in at-risk patients that can predict the development of ARDS. Experimental treatments could then be prospectively and effectively assessed in smaller, better-defined groups of patients.

We assessed the abilities of three antioxidant enzymes, manganese superoxide dismutase, catalase, and glutathione peroxidase, and three other potential markers, factor $\mathrm{VIII},{ }^{2,3}$ lactate dehydrogenase, ${ }^{4}$ and $\alpha_{1} \mathrm{Pi}$-elastase complexes, ${ }^{5,6}$ to predict the development of ARDS in patients with sepsis. Oxidant-antioxidant balance changes in ARDS and in other disease states in which oxygen radicals have been

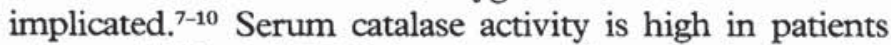
with established ARDS, but it is not known whether this abnormality arises before the development of ARDS, in which case it could be predictive, or afterwards.

\section{Patients and methods}

Written consent was obtained from each patient or a close relative. The subjects were studied with a protocol approved by our hospital's human subjects review committee. Eligible patients $(n=26)$ were identified within $8 \mathrm{~h}$ of the diagnosis of sepsis, which was defined as a serious bacterial infection and either a rectal or core temperature above $39^{\circ} \mathrm{C}$ or a peripheral leucocyte count of more than $1.2 \times 10^{10} / \mathrm{L}$ or more than $20 \%$ immature neutrophils. For a diagnosis of sepsis at least one of the following was also required: a positive blood culture of a commonly accepted pathogen, a strongly suspected or proven source of systemic infection, large amounts of pus in a closed space, unexplained systemic arterial hypotension (systolic pressure below $80 \mathrm{~mm} \mathrm{Hg}$ ), systemic vascular resistance less than 800 dyne $\mathrm{s} \mathrm{cm}^{2}$, or unexplained metabolic acidosis. ${ }^{11}$

Criteria for ARDS were acute respiratory failure requiring mechanical ventilation, bilateral pulmonary infiltrates, pulmonary

ADDRESSES. Webb-Waring Institute for Biomedical Research (J. A. Leff, MD, C. E Day, BS, J. M. McCord, PhD, J. E. Repine, MD) and Departments of Medicine and Surgery, Denver General Hospital, University of Colorado (P. E Parsons, MD, F. A. Moore, MD, E. E. Moore, MD), Denver, Colorado, USA; Department of Biochemistry, Osaka University Medical School, Osaka, Japan (N. Taniguchi, MD), and Department of Clinical Biochemistry, University of Munich, Germany (M. Jochum, PhD, H. Fritz, PhD). Correspondence to $\mathrm{Dr}$ Jonathan A. Leff, Webb-Waring Institute for Biomedical Research, 4200 East Ninth Avenue, Box C322, Denver, Colorado 80262 , USA. 

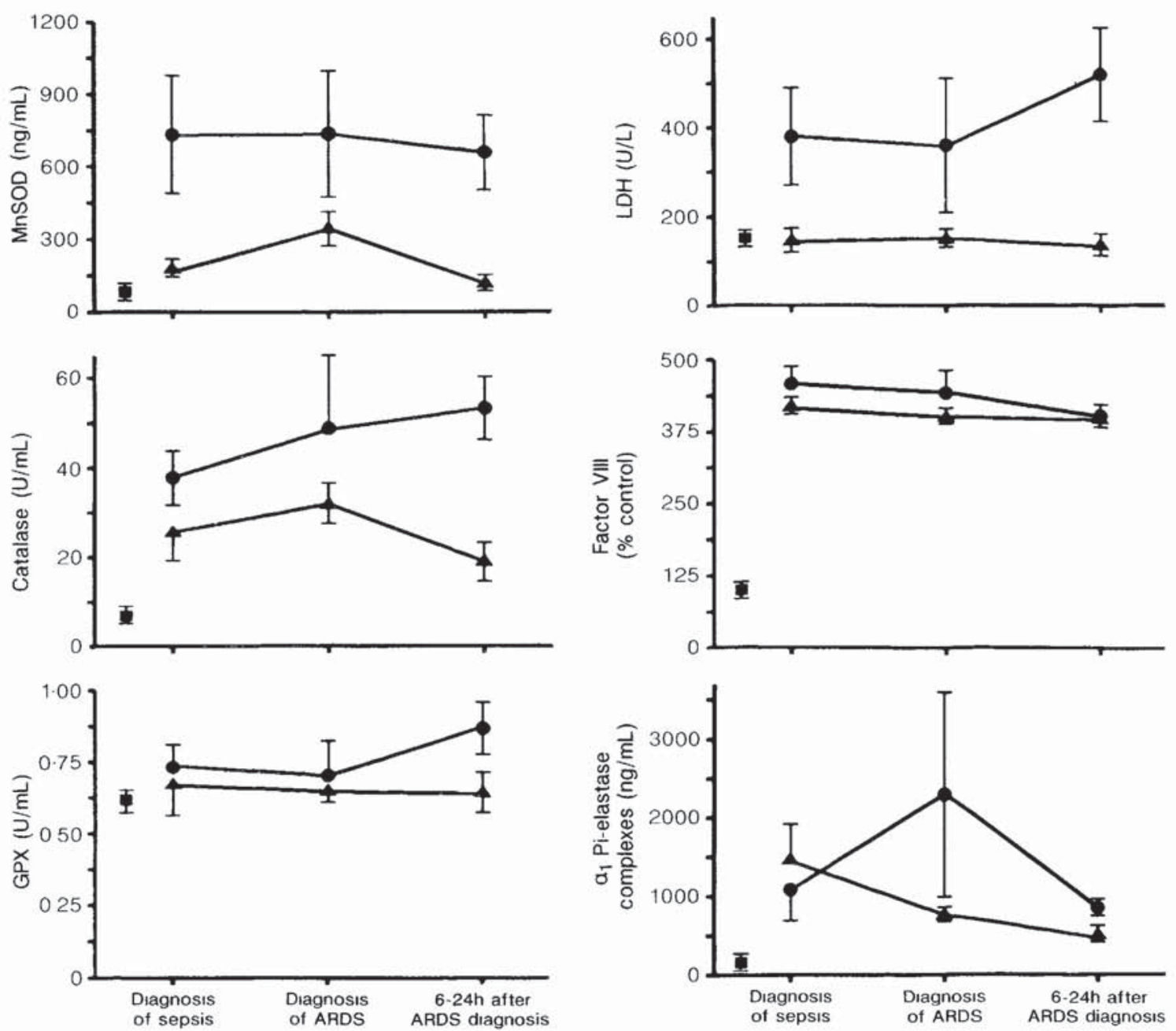

Blood marker profiles.

= septic patients with ARDS; $\mathbf{A}=$ septic patients without ARDS; $\mathbf{w}=$ healthy controls. Points are means (SE) of 3-20 measurements

$\mathrm{MnSOD}=$ manganese superoxide dismutase; $\mathrm{GPX}=$ glutathione peroxidase; $\mathrm{LDH}=$ lactate dehydrogenase.

capillary wedge pressure below $18 \mathrm{~mm} \mathrm{Hg}$, static pulmonary compliance below $50 \mathrm{~mL} / \mathrm{cm}$ water, and ratio of arterial to alveolar partial pressure of oxygen of less than $0 \cdot 25 .{ }^{11}$ Blood samples were taken at the diagnosis of sepsis $(0 \mathrm{~h})$ and also $6,12,24$, and $48 \mathrm{~h}$ later. ARDS developed in 6 patients $6-24 \mathrm{~h}$ after the diagnosis of sepsis. Samples were also obtained when ARDS was diagnosed and 6-24h later either through an indwelling arterial or venous catheter or by direct venepuncture. All patients were prospectively and sequentially studied until death or discharge. Assays were done by staff unaware of the diagnoses. 15 healthy subjects were studied as controls.

Manganese superoxide dismutase, ${ }^{12}$ factor VIII antigen ${ }^{13}$ and $\alpha_{1}$ Pi-elastase complexes $^{14}$ were measured by enzyme-linked immunosorbent assays (ELISAs). The ELISA for manganese superoxide dismutase had a sensitivity of $2 \mathrm{ng} / \mathrm{mL}$ and a coefficient of variation of less than $3 \%$. Catalase was assayed by polarographic measurement of oxygen production; ${ }^{8} 10 \mu \mathrm{L}$ serum was added to 10 $\mathrm{mmol} / \mathrm{L}$ hydrogen peroxide in $400 \mu \mathrm{L}$ Hanks' balanced salt solution in an airtight, temperature-controlled chamber, which was stirred continuously. Oxygen production was measured with an oxygen electrode, calibrated daily. $1 \mathrm{U}$ catalase activity was defined as the amount of enzyme that consumed $1 \mu$ mole of hydrogen peroxide per min at $25^{\circ} \mathrm{C}$. The assay had a sensitivity of about $0.5 \mathrm{U} / \mathrm{mL}$ and a coefficient of variation below $5 \%$. Glutathione peroxidase was measured spectrophotometrically by the oxidation of NADPH at $340 \mathrm{~nm}$ in glutathione reductase, glutathione, and $t$-butyl hydroperoxide. ${ }^{15}$ Lactate dehydrogenase ${ }^{15}$ and albumin were assayed spectrophometrically and uric acid by high-performance liquid chomatography.

Patients with and without ARDS and healthy controls were compared by analysis of variance with a Student-Newman-Keuls test of multiple comparisons. An unpaired $t$ test was used to compare the clinical characteristics of septic patients with and without ARDS. For sensitivity, specificity, positive and negative predictive values, and efficiency, $95 \%$ CIs were calculated based on the binomial distribution.

\section{Results}

The patients with and without ARDS were similar $(p>0.05)$ in terms of age, sex, packed-cell volume, haemoglobin concentration, blood leucocyte and neutrophil counts, serum alanine aminotransferase activity, serum concentrations of bilirubin, albumin, and uric acid, and APACHE II score, as reported previously. ${ }^{8,11} 3$ of the 6 patients in whom ARDS developed and 6 of the 20 without ARDS died.

Patients with sepsis had higher serum manganese superoxide dismutase concentrations than did control subjects (figure). However, at the time of diagnosis of sepsis (6-24 h before ARDS was diagnosed in 6 patients) the patients who progressed to ARDS had higher serum concentrations of this enzyme than did patients who did not develop ARDS $(p<0.05)$. The concentrations remained high for the next $48 \mathrm{~h}$ in the ARDS group but returned to control values in the non-ARDS patients. Similarly, at the time of diagnosis of sepsis, serum catalase activity was higher in patients with sepsis than in control subjects $(p<0.05)$ and in turn patients who later developed ARDS had higher 


\begin{tabular}{|c|c|c|c|c|c|c|}
\hline \multirow[b]{2}{*}{-} & \multirow[b]{2}{*}{ Cutoff } & \multicolumn{5}{|c|}{ Value (\%) and $95 \% \mathrm{Cl}$} \\
\hline & & Sensitivity & Specificity & $\begin{array}{l}\text { Positıve } \\
\text { predictive } \\
\text { value }\end{array}$ & $\begin{array}{c}\text { Negative } \\
\text { predictive } \\
\text { value }\end{array}$ & Efficiency* \\
\hline $\begin{array}{l}\text { MnSOD } \\
\text { Catalase } \\
\text { GPX } \\
\text { L.DH } \\
\text { Factor VIII } \\
\alpha_{1} \text { Pi-elastase }\end{array}$ & $\begin{array}{c}\geqslant 450 \mathrm{ng} / \mathrm{mL} \\
\geqslant 30 \mathrm{U} / \mathrm{mL} \\
\geqslant 0.72 \mathrm{U} / \mathrm{mL} \\
\geqslant 250 \mathrm{U} / \mathrm{L} \\
\geqslant 445 \% \text { control } \\
\geqslant 940 \mathrm{ng} / \mathrm{mL}\end{array}$ & $\begin{array}{l}67(42-94) \\
83(61-99) \\
50(27-85) \\
67(42-94) \\
83(61-99) \\
67(37-98)\end{array}$ & $\begin{array}{l}88(75-98) \\
65(49-82) \\
47(31-69) \\
78(62-92) \\
67(42-94) \\
64(50-80)\end{array}$ & $\begin{array}{l}67(42-94) \\
42(25-68) \\
25(12-53) \\
50(29-81) \\
45(27-73) \\
18(8-47)\end{array}$ & $\begin{array}{c}88(75-98) \\
93(81-100) \\
73(53-92) \\
88(74-98) \\
92(80-100) \\
94(84-100)\end{array}$ & $\begin{array}{l}83(70-94) \\
69(55-84) \\
48(34-66) \\
75(61-89) \\
71(57-85) \\
64(51-79)\end{array}$ \\
\hline
\end{tabular}

$\mathrm{MnSOD}=$ manganese superoxide dismutase; $\mathrm{GPX}=$ glutathione peroxıdase, $\mathrm{LDH}=$ lactate dehydrogenase

*True results as a percentage of all results.

$(\mathrm{p}<0.05)$ serum catalase activity than the non-ARDS patients (figure). During the next $48 \mathrm{~h}$, serum catalase activity increased progressively in patients who developed ARDS but decreased in the other patients. By contrast, we found no significant difference between control subjects and sepsis patients with or without subsequent ARDS in serum glutathione peroxidase activity.

Serum lactate dehydrogenase activity was also significantly higher in patients who subsequently developed ARDS than in patients who did not progress to ARDS $(p<0.05)$; the latter had activities similar to those of the controls. Lactate dehydrogenase activity increased during the study period in sepsis patients who developed ARDS but not in the other groups.

For factor VIII, serum concentrations were higher in patients with sepsis than in the healthy controls but there were no significant differences between septic patients with and without ARDS. Plasma concentrations of $\alpha_{1}$ Pi-elastase complexes also were higher in septic patients than controls at diagnosis of sepsis, but the difference between patients who did and did not develop ARDS was significant $(p<0.05)$ only when ARDS had been diagnosed.

We found no correlations at any time among the six markers. When we calculated indices of the markers' ability to predict ARDS development, based on cutoff points chosen by inspection of the data to provide the best separation of ARDS and non-ARDS subjects, the positive and negative predictive values and the sensitivity and specificity of serum manganese superoxide dismutase concentrations (above or equal to a cutoff of $450 \mathrm{ng} / \mathrm{mL}$ ), catalase activity ( $30 \mathrm{U} / \mathrm{mL}$ or above), lactate dehydrogenase activity ( $250 \mathrm{U} / \mathrm{L}$ or above), and factor VIII concentrations ( $445 \%$ of control values or more) were similar in predicting the development of ARDS in patients with sepsis (table). Manganese superoxide dismutase, catalase, and lactate dehydrogenase values exceeded the chosen cutoff values $9 \mathrm{~h}$, $12 \mathrm{~h}$, and $12 \mathrm{~h}$, respectively, before ARDS was diagnosed.

\section{Discussion}

We have found that $9-12 \mathrm{~h}$ before the development of ARDS, amounts of two serum antioxidant enzymes were increased in sepsis patients who later developed ARDS compared with patients who did not develop ARDS; both factors predicted the development of ARDS in sepsis patients with sensitivity, specificity, and efficiency equal to those of lactate dehydrogenase and factor VIII measurements.

Assessment of serum manganese superoxide dismutase and catalase could be useful for defining the pathogenesis of ARDS or for identifying patients with similar characteristics. Each measurement is accessible, repeatable, and easy to do. Use of these assessments could facilitate study of prophylactic treatment by reducing the number of at-risk patients needed. Our findings may also have functional importance. These antioxidant enzymes can diminish oxidant insults mediated by superoxide anion, hydrogen peroxide, and their products such as hydroxyl radicals. Accelerated intravascular generation of oxygen radicals from stimulated neutrophils, circulating xanthine oxidase, and other sources has been implicated in the pathogenesis of sepsis and ARDS. ${ }^{1}$

Since the time courses for the various markers differed and no two markers were intercorrelated, our findings suggest that each factor represents a distinct process and that the factors reflect various processes that occur in septic patients with ARDS rather than in ARDS itself. This study focused on sepsis-induced ARDS, and different mechanisms may be present in ARDS that develops after trauma or in other conditions. It is not clear where the markers are produced. Lung tissue injury is a possible source for higher than normal production of lactate dehydrogenase, factor VIII, and the two antioxidant enzymes. Endothelial cells are rich in these substances and, if perturbed, could readily increase the amounts in blood. However, intravascular neutrophil activation must bring about increases in $\alpha_{1}$ Pi-elastase complexes, since elastase is present only in neutrophils. Changes in $\alpha_{1}$ Pi-elastase complexes occurred later than the other changes at diagnosis of ARDS, and concentrations had fallen to normal by $48 \mathrm{~h}$ after the diagnosis of sepsis, perhaps indicating a decline in neutrophil activity. Red blood cell haemolysis is a plausible source for increased amounts of serum catalase and lactate dehydrogenase, but not manganese superoxide dismutase or factor VIII. Serum catalase activity is increased in the serum of rats subjected to skin burns ${ }^{16}$ and in patients with acquired immunodeficiency syndrome, ${ }^{7}$ but again the source is unclear. High concentrations of interleukin-1, tumour necrosis factor, and endotoxin have been found in ARDS patients ${ }^{17}$ and can cause increases in antioxidants such as manganese superoxide dismutase and catalase. ${ }^{18-20}$ Perhaps increases in antioxidants reflect activation of intrinsic antioxidant tolerance mechanisms mediated by cytokines. ${ }^{21}$

We thank Ms Jacqueline Smith for graphics, the patient care staff at Denver General Hospital, Mr Michael Owens and Ms May Gillespie for technical assistance, and Dr Lisa Beth Ferstenberg and Mr Kyle Davis for expert help with statistical analysis.

J. A. L. was in receipt of a clinician-scientist award from the American Heart Association and P. E. P. a clinical investigator award from the National Institutes of Health (HL-01849). The study was supported by grants from the National Institutes of Health (HL 40784, 45582), Colorado Heart Association, Council for Tobacco Research, Ronald McDonald Children's Charities, Johnson and Johnson, Williams Family, Swan, Hill, Kleberg, Donner, and American Express Foundations. 


\section{REFERENCES}

1. Repine JE. Scientific perspectives on adult respiratory distress syndrome. Lancet 1992; 339: 466-69.

2. Carvalho ACA, Bellman SM, Saullo VJ, Quinn D, Zapol WM. Altered factor VIII in acute respiratory failure. $N$ Engl $f$ Med 1982; 307: 1113-19.

3. Rubin DB, Wiener-Kronish JP, Murray JF, et al. Elevated von Willebrand factor antigen is an early plasma predictor of acute lung injury in non-pulmonary sepsis syndrome. $f$ Clin Invest 1990; 86: 474-80.

4. Dwenger A, Regel G, Schweitzer G, Rollig G, Lindena J. Nonspecific immune system, plasma proteins and characteristics of the erythrocyte insulin receptor. In: Sturm JA, ed. Adult respiratory distress syndrome. Berlin: Springer-Verlag, 1991: 91-127.

5. Rocker GM, Pearson D, Wiseman MS, Shale DJ. Diagnostic criteria for adult respiratory distress syndrome: time for reappraisal. Lancet 1989; i: $120-23$.

6. Hilgenfeldt U, Kellermann W, Kienapfel G, Jochum M. Relationship between angiotensinogen, $\alpha_{1}$-protease inhibitor elastase complex, antithrombin III and C-reactive protein in septic ARDS. Eur F Clin Pharmacol 1990 38: 125-31.

7. Leff JA, Oppegard MA, Curiel TJ, Brown KS, Schooley RT, Repine JE. Progressive increases in serum catalase activity in advancing human immunodeficiency virus infection. Free Radical Biol Med 1992; 13: $143-49$.

8. Leff JA, Parsons PE, Day CE, et al. Increased serum catalase activity in septic patients with the adult respiratory distress syndrome. Am Rev Respor Dis 1992; 146: 985-89.

9. Buhl R, Holroyd KJ, Mastrangeli A, et al. Systemic glutathione deficiency in symptom-free HIV-seropositive individuals. Lancet 1989; ii: $1294-98$.

10. Pacht ER, Timerman AP, Lykens MG, Merola AJ. Deficiency of alveolar fluid glutathione in patients with sepsis and the adult respiratory distress syndrome. Chest 1991; 100: 1397-403.
11. Parsons PE, Worthen GS, Moore EE, Tate RM, Henson PM. The association of circulating endotoxin with the development of the adult respiratory distress syndrome. Am Rev Resp Dis 1989; 140: 294-301.

12. Kawaguchi T, Takeyasu A, Matsunobu K, et al. Stimulation of Mn-superoxide dismutase expression by tumor necrosis factor-alpha: quantitative determination of Mn-SOD protein levels in TNFresistant and sensitive cells by ELISA. Biochem Biophys Res Commun 1990; 171: 1378-86.

13. Cejka J. Enzyme immunoassay for factor VIII-related antigen. Clin Chem 1982; 28 : $1356-58$.

14. Duswald KH, Jochum M, Schramm W, Fritz H. Released granulocytic elastase: an indicator of pathochemical alterations in septicemia after abdominal surgery. Surgery 1985; 98: 892-99.

15. Beutler E. Red cell metabolism: a manual of biochemical methods. Orlando: Grune \& Stratton, 1984: 1-172.

16. Leff JA, Burton LK, Berger EM, Anderson BO, Wilke CP, Repine JE. Increased serum catalase activity in rats subjected to thermal skin injury. Inflammation 1993; 17: 199-204.

17. Suter PM, Suter S, Girardin E, Roux-Lombard P, Grau GE, Dayer J. High bronchoalveolar levels of tumor necrosis factor and its inhibitors, interleukin-1, interferon, and elastase, in patients with adult respiratory distress syndrome after trauma, shock, or sepsis. Am Rev Resp Dis 1992; 145: 1016-22.

18. White CW, Ghezzi P, McMahon S, Dinarello CA, Repine JE. Cytokines increase rat lung antioxidant enzymes during exposure to hyperoxia. I Appl Physiol 1989; 66: 1003-07.

19. Wong GHW, Goeddel DV. Induction of manganous superoxide dismutase by tumor necrosis factor: possible protective mechanism. Science 1988; 242: 941-44.

20. Taniguchi N. Clinical significances of superoxide dismutases: changes in aging, diabetes, ischemia, and cancer. Adv Clin Chem 1992; 29: 1-59.

21. Brown JM, White CW, Terada LS, et al. Interleukin 1 pretreatment decreases ischemia/reperfusion injury. Proc Natl Acad Sci USA 1990; 87: 5026-30. 